\title{
Evidence for an increased distribution range of Dermacentor reticulatus in south-west Poland
}

\author{
Dorota Kiewra $\cdot$ Aleksandra Czulowska
}

Received: 1 June 2012/ Accepted: 13 September 2012/Published online: 13 October 2012

(C) The Author(s) 2012. This article is published with open access at Springerlink.com

\begin{abstract}
The expansion of Dermacentor reticulatus to new geographical areas has been observed in several countries in Europe, including Poland and it's neighbors. In 2011 and 2012, a total of 148 host-seeking D. reticulatus ticks were collected after flagging the vegetation in Lower Silesia, south-western Poland. Tick monitoring was conducted in mixed and deciduous forest, on meadows, in river valleys and ecotones between forested and grassy areas. The ornate dog ticks were found in 10 out of 33 sites located in five districts: Legnica, Wroclaw, Środa Śląska, Lubin and Boleslawiec County. All sites where D. reticulatus ticks were found are located to the south-west of the Odra River. The greatest distance between these disconnected localities was approximately $90 \mathrm{~km}$. It seems that at present the southern boundary of the range is Wroclaw district. This study indicates that $D$. reticulatus can be ranked as a typical element of the fauna in Lower Silesia in southwestern Poland.
\end{abstract}

Keywords Dermacentor reticulatus · Poland · Geographical distribution · Change the range

\section{Introduction}

There are 36 known Dermacentor tick species worldwide (Barker and Murrell 2008), and two of them have been found in Poland: Dermacentor reticulatus (the ornate dog tick or the ornate cow tick) and D. marginatus (the ornate sheep tick). According to Siuda (1993) D. marginatus was collected in Poland only from wild boar (Sus scrofta) (only a few specimens in the Kłodzko Valley, Lower Silesia, south-western Poland) and it can be consider as a transferred species (Nowak 2010a), whereas D. reticulatus was commonly found in north-eastern Poland. Taking into account habitats of mature tick stages it can be classified as non-nidicolous, whereas nymphs and larvae attack small mammals in burrows and can be classified as nidicolous. Adults feed on larger mammals like deer and dogs but

D. Kiewra $(\bowtie) \cdot$ A. Czulowska

Institute of Genetics and Microbiology, University of Wroclaw, Wrocław, Poland

e-mail: dorota.kiewra@microb.uni.wroc.pl 
only occasionally bite humans (Dautel et al. 2006). Consequently, immature stages were only found on hosts, whereas adults can be collected both from the hosts and the vegetation. In Poland, D. reticulatus ticks inhabit mostly river valleys, lake shores, meadows and clearings, preferring natural boggy mixed and deciduous forests connected to a watercourse, where there is a relatively high ground water table (Siuda 1993; Karbowiak 2009).

The distribution of the ornate dog tick is known in the western Palearctic region, in a temperate climate zone from England and France in the west, to the basin of Yenisei River in Siberia in the east (Siuda 1993). It has not been found north of $53-54^{\circ} \mathrm{N}$ latitude nor in the Mediterranean climate zone (Dautel et al. 2006). However, a case of babesiosis caused by Babesa canis canis in a dog in Norway suggest possibility of expansion $D$. reticulatus even further northwards (Øines et al. 2010). Within the geographic range, the ornate dog tick, is distributed in a highly focal pattern (Gray et al. 2009). However, the range of the ornate dog tick occurrence is divided into two separate localities. In western Europe it includes areas in England, France, Switzerland, Germany, Austria, whereas in eastern Europe it extends from north-eastern Poland across Lithuania, Belarus, Ukraine to the European part of Russia. Therefore, the western part of Poland was considered to be a region free from $D$. reticulatus. Karbowiak (2009) indicates the triangular sharp area, where $D$. reticulatus has been absent. The north border of this triangle ranges along the Baltic seaside, whereas the arms extended from central Germany, from the 12-13th meridian longitude East to the 19th meridian in Poland, and coincides with the southern border of Hungary. However, in recent years, the range of this species has been extended substantially and new localities of $D$. reticulatus have been found.

The present study for the first time shows that D. reticulatus can be ranked as a typical element of the fauna in Lower Silesia in south-western Poland.

\section{Materials and methods}

Host-seeking ticks were collected using a flagging method in Lower Silesia, in southwestern Poland. The study was conducted in 33 localities from Godnowa (N51 33.460 E017 18.986$)$ in the North to Świebodzice (N50 54.412 E016 23.948$)$ in the South (Fig. 1). Different type of habitats were selected: in 2011 (April-June and September), sampling of ticks was carried out in habitats preferred by Ixodes ricinus ticks (mixed and deciduous forest), while in 2012 (March-April), tick monitoring was conducted also on meadows, in the river valleys, and ecotones between forested and grassy areas. Ticks were collected in daytime between 9 a.m. and 5 p.m. Each single site was flagged for at least 30 min. Collected ticks were stored in $70 \%$ ethanol. Adult ticks were separated by sex, and identified to the species level under stereomicroscope by using the key in a monographic work of Siuda (1993).

\section{Results}

A total of 148 D. reticulatus ticks were collected from vegetation in 10 out of 33 sites in Lower Silesia, south-western Poland (Fig. 1; Table 1). In 2011, ten host-seeking D. reticulatus ticks ( 5 female and 5 male) were collected using a flagging method, among I. ricinus from three sites located in the Legnica County (Mierzowice, Motyczyn, Rogów Legnicki). In 2012, 138 questing D. reticulatus ticks (84 female and 54 male) were found. 


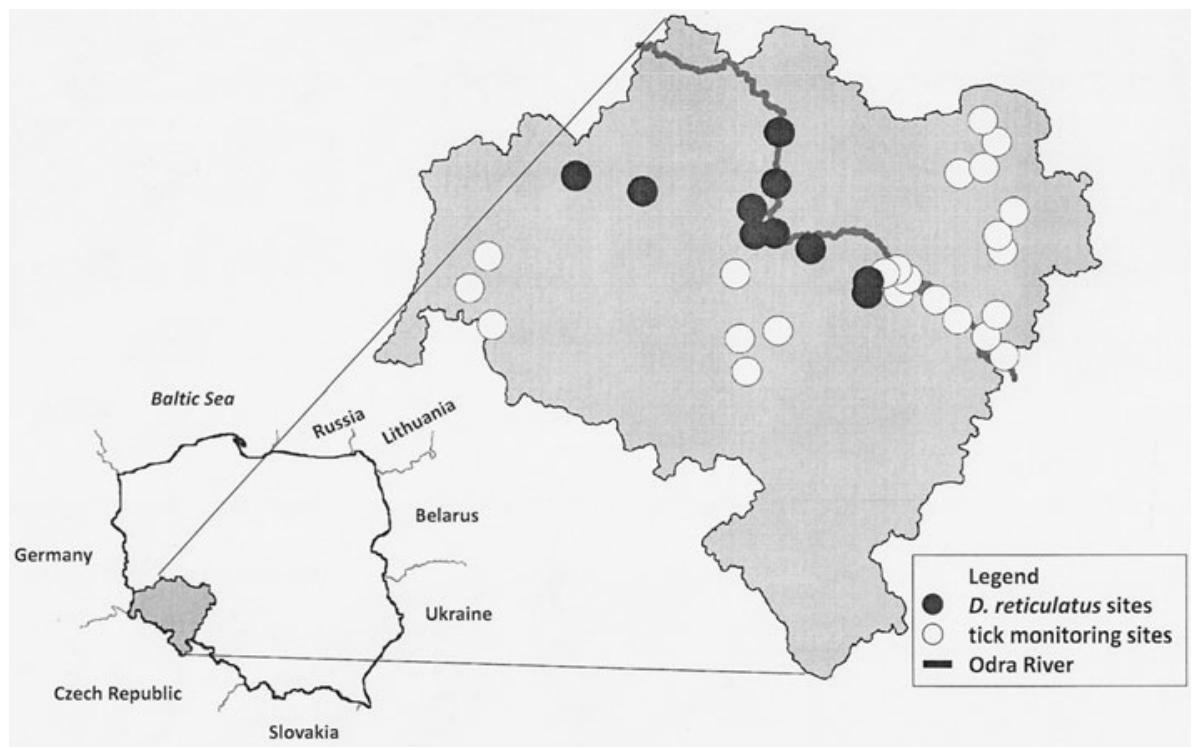

Fig. 1 Tick monitoring habitats and collection sites of Dermacentor reticulatus in Lower Silesia, Poland

In 2012, the occurrence of $D$. reticulatus ticks was confirmed in all three sites selected in 2011, and additionally in seven new sites located in five districts: the Legnica County (Rokitki), the Lubin County (Naroczyce, Dziewiń), the Wroclaw County (Wroclaw, Samotwór), the Bolesławiec County (Trzebień), the Środa Śląska County (Szczepanów). All sites where $D$. reticulatus ticks were found are located to the south-west of the Odra River. The distance between the most distant localities, where D. reticulatus ticks were found, is approximately $90 \mathrm{~km}$.

\section{Discussion}

The expansion of $D$. reticulatus into new areas has been observed in several European countries, including Poland and it's neighbouring states. Climate change, increased deer abundance, and antropogenic factors together with more fallow land may be responsible for the change in the distribution (Gray et al. 2009). Colonization of new sites is known from Germany (Dautel et al. 2006; Gray et al. 2009), the Netherlands (Nijhof et al. 2007), Slovakia (Bullová et al. 2009), the Czech Republic (Široký et al. 2011). In Germany, D. reticulatus has expanded its range particularly in the eastern and southwestern parts of country (Gray et al. 2009). Dogs and deer infested with D. reticulatus as well as specimens in the field, were found in Brandenburg. In Saxony deer were found to be harbouring $D$. reticulatus (Dautel et al. 2006). Thus, the ornate dog ticks were found in the German land bordering western Poland. On the other hand, the closest position of D. reticulatus ticks to the south-west border of Poland is confirmed only in south-east part of the Czech Republic in the South Moravian Region, where north-west distribution limits of this species were defined (Široký et al. 2011). In Poland, the occurrence of D. reticulatus ticks is known, however only a north-east part of the country is considered as a typical location. Earlier and present works confirm locations mainly in the Warmian-Masurian, the Podlaskie, and 
Table 1 The number of Dermacentor reticulatus ticks collected in 10 sites in Lower Silesia in years 2011-2012

\begin{tabular}{|c|c|c|c|c|c|c|}
\hline \multirow[t]{2}{*}{ Site no. } & \multirow[t]{2}{*}{ Years } & \multirow[t]{2}{*}{ Locality } & \multirow[t]{2}{*}{ Geographical coordinates } & \multicolumn{2}{|c|}{ Number of D. reticulatus } & \multirow[t]{2}{*}{ Density $^{a}$} \\
\hline & & & & Females & Males & \\
\hline 1 & \multirow[t]{3}{*}{2011} & Motyczyn & 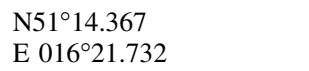 & 1 & 0 & 1 \\
\hline 2 & & Mierzowice & $\begin{array}{l}\text { N } 51^{\circ} 17.787 \\
\text { E } 016^{\circ} 20.802\end{array}$ & 3 & 5 & 4 \\
\hline 3 & & Rogów Legnicki & $\begin{array}{l}\text { N } 51^{\circ} 14.726 \\
\text { E } 016^{\circ} 26.887\end{array}$ & 1 & 0 & 0.5 \\
\hline 1 & \multirow[t]{10}{*}{2012} & Motyczyn & $\begin{array}{l}\text { N } 51^{\circ} 14.367 \\
\text { E } 016^{\circ} 21.732\end{array}$ & 8 & 4 & 4 \\
\hline 2 & & Mierzowice & $\begin{array}{l}\text { N } 51^{\circ} 17.787 \\
\text { E } 016^{\circ} 20.802\end{array}$ & 14 & 13 & 5.4 \\
\hline 3 & & Rogów Legnicki & $\begin{array}{l}\text { N } 51^{\circ} 14.726 \\
\text { E } 016^{\circ} 26.887\end{array}$ & 6 & 1 & 2.3 \\
\hline 4 & & Naroczyce & $\begin{array}{l}\text { N } 51^{\circ} 31.246 \\
\text { E } 016^{\circ} 27.247\end{array}$ & 41 & 33 & 12.3 \\
\hline 5 & & Dziewin & $\begin{array}{l}\text { N } 51^{\circ} 21.725 \\
\text { E } 016^{\circ} 27.948\end{array}$ & 2 & 0 & 0.7 \\
\hline 6 & & Wrocław (Jarnoltow) & $\begin{array}{l}\text { N } 51^{\circ} 07.555 \\
\text { E } 016^{\circ} 50.409\end{array}$ & 3 & 1 & 4 \\
\hline 7 & & Szczepanow & $\begin{array}{l}\text { N } 51^{\circ} 12.320 \\
\text { E } 016^{\circ} 37.355\end{array}$ & 3 & 1 & 4 \\
\hline 8 & & Trzebień & $\begin{array}{l}\mathrm{N} 51^{\circ} 22.033 \\
\text { E } 015^{\circ} 36.015\end{array}$ & 3 & 1 & 2 \\
\hline 9 & & Samotwór & $\begin{array}{l}\text { N } 51^{\circ} 06.562 \\
\text { E } 016^{\circ} 49.957\end{array}$ & 1 & 0 & 0.5 \\
\hline 10 & & Rokitki & $\begin{array}{l}\text { N } 51^{\circ} 19.603 \\
\text { E } 015^{\circ} 53.603\end{array}$ & 3 & 0 & 1.5 \\
\hline
\end{tabular}

a The average number of $D$. reticulatus ticks collected by one person during $30 \mathrm{~min}$

the Lublin Voivodship, along the border with Lithuania, Belarus, and Ukraine (Szymański 1977; Siuda 1993; Bogdaszewska 2005; Biaduń et al. 2007; Bartosik et al. 2011). However, the expansion towards west is observed for several years. D. reticulatus ticks were noted in the Pomeranian, the Kuyavian-Pomeranian, and West-Pomeranian Voivodship to the West of the Vistula River (Fryderyk 1998, Kadulski and Izdebska 2009), in the Masovian Voivodeship (Karbowiak 2009). In the present study, new sites of D. reticulatus ticks in south-western Poland were found. The first evidence of the ornate dog tick occurrence in Lower Silesia was noted in 2009, when a few species in the Boleslawiec County were collected (Karbowiak and Kiewra 2010). The Boleslawiec locality as $D$. reticulatus tick colonized area was confirmed in the present study. In addition, the $D$. reticulatus was found on 9 additional sites, including three sites where this species was collected both in 2011 and 2012. This results indicate the constant presence of this species in Lower Silesia. The occurrence of D. reticulatus in Western Poland was also recently discovered in 2010 in the Lubuskie Province as a "Lubuskie Focus", about $55 \mathrm{~km}$ from the Polish-German border (Nowak 2010b). Taking into account the present study (the distance between sites was about $90 \mathrm{~km}$ ) and the $70 \mathrm{~km}$ distance between currently data from Naroczyce, the most northerly located position in 2012, and "Lubuskie Focus" it is 
necessary to consider the change of the D. reticulatus range. What's more it may be the extension of the West European population. It seems that at present the south boundary of the range is Wrocław district.

The knowledge of tick distribution is particularly important from a medical and veterinary point of view because of a variety of pathogens transmitted, including viruses, bacteria and protozoa. D. reticulatus ticks are known to transmit Babesia spp., Rickettsia spp., Francisella tularensis, Coxiella burnetii. Endemic regions for canine babesiosis caused by B. canis are the same as endemic regions for D. reticulatus (Zygner et al. 2009). In Slovakia, according to Bullová et al. (2009) the occurrence of babesiosis preceded the founding of $D$. reticulatus in the East Slovak Lowland. Also the occurrence of canine babesiosis in new areas of Germany, Hungary, Switzerland and the Netherlands provided the changing distribution of the ornate dog ticks (Gray et al. 2009). Simultaneously with the appearance of D. reticulatus in Lower Silesia, there is danger of spreading not only canine babesiosis, but also other tick-borne diseases like rickettsiosis. In Germany, Dautel et al. (2006) detected almost one quarter of the D. reticulatus positive for Rickettsia sp. and in Saxony, Silaghi et al. (2011) over $65 \%$. A high proportion of infected ticks (over $40 \%$ ) was found also in north-eastern Poland (Stańczak 2006). In Poland, the first case of ricketsiosis TIBOLA/DEBONEL was described in 2011 (Chmielewski et al. 2011). The expansion of ticks in new areas may also cause the appearance of tick-borne encephalitis virus. According Wójcik-Fatla et al. (2011) the infection rate with TBEV of D. reticulatus in eastern Poland was much higher than the infection rate of I. ricinus.

The expansion of ticks to new area can increase a risk of tick-borne diseases. Thus, the environmental monitoring of changes in the range of $D$. reticulatus is crucial for assessment the epidemiological risk. The confirmed occurrence of the ornate dog ticks in southwest Poland provided evidence that this species has extended its range. It indicates a need of future systematic sampling to assess a speed of spread.

Open Access This article is distributed under the terms of the Creative Commons Attribution License which permits any use, distribution, and reproduction in any medium, provided the original author(s) and the source are credited.

\section{References}

Barker SC, Murrell A (2008) Systematic and evolution of ticks with a list of valid genus and species names. In: Bowman AS, Nuttall PA (eds) Ticks, biology, diseases and control. Cambridge University Press, Cambridge, pp 1-39

Bartosik K, Wiśniowski Ł, Buczek A (2011) Abundance and seasonal activity of adult Dermacentor reticulatus (Acari: Amblyommidae) in eastern Poland in relation to meteorological conditions and the photoperiod. Ann Agric Environ Med 18:340-344

Biaduń W, Chybowski J, Najda N (2007) A new records of Dermacentor reticulatus (Fabricius, 1794) in Lublin region. Wiad Parazytol 53:29-32

Bogdaszewska Z (2005) Występowanie i ekologia kleszcza łąkowego Dermacentor reticulatus (Fabricius, 1794) w ognisku mazurskim. IV. Wyniki badań określeniem specyficzności żywicielskiej. (Range and ecology of Dremacentor reticulatus (Fabricius, 1794) in Mazuria Focus. IV. Host specify). Wiad Parazytol 51:39-42

Bullová E, Lukáň M, Stanko M, Pet'ko B (2009) Spatial distribution of Dermacentor reticulatus tick in Slovakia in the beginning of the 21st century. Vet Parasitol 165:357-360

Chmielewski T, Rudzka D, Fiecek B, Mączka I, Tylewska-Wierzbanowska S (2011) Case of TIBOLA/ DEBONEL (tick-borne lymphadenopathy/Dermacentor spp. borne necrosis-erythema-lymphadenopathy) in Poland. Przegl Epidemiol 65:583-586

Dautel H, Dippel C, Oehme R, Hartelt K, Schettler E (2006) Evidence for an increased geographical distribution of Dermacentor reticulatus in Germany and detection of Rickettsia sp. RpA4. Int J Med Microbiol 296(Suppl 40):149-156 
Fryderyk S (1998) Nowe interesujące stwierdzenie Dermacentor reticulatus (Fabr.) (Acari, Ixodidae) na dziku (Sus scrofa L.). Wiad Parazytol 44:737-739

Gray JS, Dautel H, Estrada-Peña A, Kahl O, Lindgren E (2009) Effects of climate change on ticks and tickborne diseases in Europe. Interdiscip Perspect Infect Dis Article ID 2009:593232. doi:10.1155/2009/ 593232

Kadulski S, Izdebska JN (2009) New data on distribution of Dermacentor reticulatus (Fabr.) (Acari, Ixodidae) in Poland. In: Buczek A, Błaszak C (eds) Stawonogi. Inwazje i ich ograniczanie. Lublin, Akapit, pp 53-58

Karbowiak G (2009) Kleszcz łąkowy Dermacentor reticulatus-występowanie, biologia i rola jako wektora chorób odkleszczowych. Rozprawa habilitacyjna. Wyd Agencja Reklamowo-Wydawnicza A Grzegorczyk, Warszawa

Karbowiak G, Kiewra D (2010) New locations of Dermacentor reticulatus ticks in western Poland: the first evidence of the merge in D. reticulatus occurrence areas? Wiad Parazytol 56:333-340

Nijhof AM, Bodaan C, Postigo M, Nieuwenhuijs H, Opsteegh M, Franssen L, Jebbink F, Jongejan F (2007) Ticks and associated pathogens collected from domestic animals in the Netherlands. Vector Borne Zoonotic Dis 7:585-595

Nowak M (2010a) The characteristic of tick species (Acari: Ixodida) transferred on exotic reptiles to Poland. Wiad Parazytol 56:29-42

Nowak M (2010b) Discovery of Dermacentor reticulatus (Acari: Amblyommidae) populations in the Lubuskie Province (Western Poland). Exp Appl Acarol 54:191-197. doi:10.1007/s10493-010-9422-4

Øines $\varnothing$, Storli K, Brun-Hansen H (2010) First case of babesiosis caused by Babesia canis canis in a dog from Norway. Vet Parasitol 171:350-353

Silaghi C, Hamel D, Thiel C, Pfister K, Pfeffer M (2011) Renatured areas as focal points for tick-borne pathogens in Saxony, Germany. Programme and abstracts. In: XI international Jena symposium on Tick-borne Diseases 2011, p 63

Široký P, Kubelová M, Bednár M, Modrý D, Hubálek Z, Tkadlec E (2011) The distribution and spreading pattern of Dermacentor reticulatus over its threshold area in the Czech Republic - how much is range of this vector expanding? Vet Parasitol 183:130-135

Siuda K (1993) Kleszcze Polski. Acari (Ixodida). Część II. Systematyka i rozmieszczenie. (Ticks (Acari: Ixodida) od Poland. Part II. Taxonomy and distribution).Warszawa. Towarzystwo Parazytologiczne, Polskie

Stańczak J (2006) Detection of spotted fever group (SFG) rickettsiae in Dermacentor reticulatus (Acari: Ixodidae) in Poland. Int J Med Microbiol 296(S1):144-148

Szymański S (1977) Nowe ogniska Dermacentor reticulatus (Fabricius, 1794) w Polsce. (New foci of Dermacentor reticulatus (Fabricius, 1794) in Poland.). Wiad Parazytol 23:35-37

Wójcik-Fatla A, Cisak E, Zając V, Zwoliński J, Dutkiewicz J (2011) Prevalence of tick-borne encephalitis virus in Ixodes ricinus and Dermacentor reticulatus ticks collected from Lublin region (eastern Poland). Ticks Tick Borne Dis 2:16-19

Zygner W, Górski P, Wędrychowicz H (2009) New localities of Dermacentor reticulatus tick (vector of Babesia canis canis) in central and eastern Poland. Pol J Vet Sci 12:549-555 